\title{
PENGARUH CORPORATE GOVERNANCE TERHADAP INTEGRITAS LAPORAN KEUANGAN
}

\author{
Oleh: \\ Andry Priharta \\ Dosen Fakultas Ekonomi dan Bisnis \\ Universitas Muhammadiyah Jakarta \\ Email: \\ andry.priharta@umj.ac.id
}

\begin{abstract}
ABSTRAK
Penelitian ini bertujuan untuk membuktikan secara empiris pengaruh mekanisme corporate governance (kepemilikan institusional, komisaris independen, dan kualitas audit) terhadap integritas laporan keuangan pada perusahaan industri manufaktur di Indonesia. Integritas laporan keuangan sebagai variabel bebas diproksikan dengan konservatisme. Sampel penelitian terdiri atas perusahaan manufaktur yang terdaftar di Bursa Efek Indonesia pada periode 2011-2014. Dengan metode purposive sampling diperoleh 62 perusahaan sebagai sampel. Analisis dilakukan dengan regresi linier berganda, yang menunjukkan hasil bahwa kepemilikan institusional berpengaruh negatif signifikan, sementara komisaris independen dan kualitas audit berpengaruh positif signifikan, terhadap integtitas laporan keuangan.
\end{abstract}

Kata kunci : corporate governance, kepemilikan institusional, komisaris independen, kualitas audit, integritas laporan keuangan.

\section{A. PENDAHULUAN}

Akuntansi adalah bahasa bisnis. Tiga aktivitas dasar akuntansi adalah mengidentifikasi, mencatat dan mengkomunikasikan kejadian ekonomi dari sebuah organisasi kepada para pemangku kepentingan (Weygandt, et al. 2011). Akuntansi menghasilkan informasi yang menjelaskan kinerja keuangan entitas dalam suatu periode tertentu dan kondisi keuangan entitas pada tanggal tertentu (Martani, dkk., 2012). Keluaran akuntansi adalah informasi keuangan dalam bentuk laporan keuangan yang menurut Standar Akuntansi Keuangan (SAK) terdiri atas laporan posisi keuangan (neraca), laporan laba rugi komprehensif, laporan perubahan ekuitas, laporan arus kas, dan catatan atas laporan keuangan. 
Kelima laporan tersebut pada saat disusun, disajikan, dan pengungkapannya harus sesuai dengan standar akuntansi yang digunakan (Martani, dkk., 2012).

Laporan keuangan dikatakan berintegritas apabila laporan keuangan memenuhi kualitas reliability (Hardiningsih, 2010; Gayatri dan Suputra, 2013). Lebih lanjut Martani, dkk (2012) menjelaskan bahwa informasi memiliki kualitas andal (reliable) jika bebas dari pengertian yang menyesatkan, kesalahan material, dan dapat diandalkan pemakainya sebagai penyajian yang tulus atau jujur (faithful representation) dari yang seharusnya disajikan atau yang secara wajar diharapkan dapat disajikan. Untuk dapat menghasilkan laporan keuangan yang dapat dipertangungjawabkan dan bermanfaat bagi setiap penggunanya maka lahirlah konsep konservatisme (Rahiim dan Wulandari, 2014) yang dapat diproksikan sebagai integritas laporan keuangan (Gayatri dan Suputra, 2013). Konservatisme sendiri dapat diartikan bahwa jika ada penilaian pos tertentu yang tidak pasti maka dipilihlah alternatif yang paling kecil untuk aktiva dan pendapatan, bahkan pendapatan yang belum pasti, tidak diakui, tetapi kerugian yang mungkin terjadi diakui atau dicatat (Sjahrial dan Purba, 2013).

Integritas laporan keuangan secara intuitif dapat diukur melalui dua cara, yaitu dengan konservatisme serta keberadaan manipulasi laporan keuangan yang biasanya diukur dengan manajemen laba (Damayanti dan Rochmi, 2014). Berdasarkan penelitian Leuz, et al. (2002) diperoleh bukti bahwa perusahaanperusahaan di Indonesia ternyata terindikasi melakukan praktik manajemen laba. Dibandingkan dengan negara ASEAN lainnya seperti Malaysia, Filipina, Thailand dan Singapura, Indonesia bahkan dinilai merupakan negara terbesar tingkat manajemen labanya. Hal tersebut diperkuat oleh hasil penelitian Ratmono (2010) yang menunjukkan bahwa perusahaan-perusahaan publik di Indonesia melakukan manajemen laba riil dengan tujuan menghindari melaporkan kerugian tahunan.

Untuk mengkonfirmasi hasil penelitian tersebut, telah dilakukan kembali pengukuran terhadap 64 perusahaan manufaktur di Indonesia periode pelaporan keuangan tahun 2013 dan 2014. Dengan menggunakan pengukuran manajemen laba riil ternyata memang perusahaan-perusahaan manufaktur di Indonesia sebagian terindikasi melakukan praktek manajemen laba (Roychowdhury, 2006) yang dapat dilihat melalui grafik 1 di bawah ini.

\section{Gambar 1. \\ Manajemen Laba Riil - Dampak Gabungan Perusahaan Manufaktur di Indonesia 2013-2014}

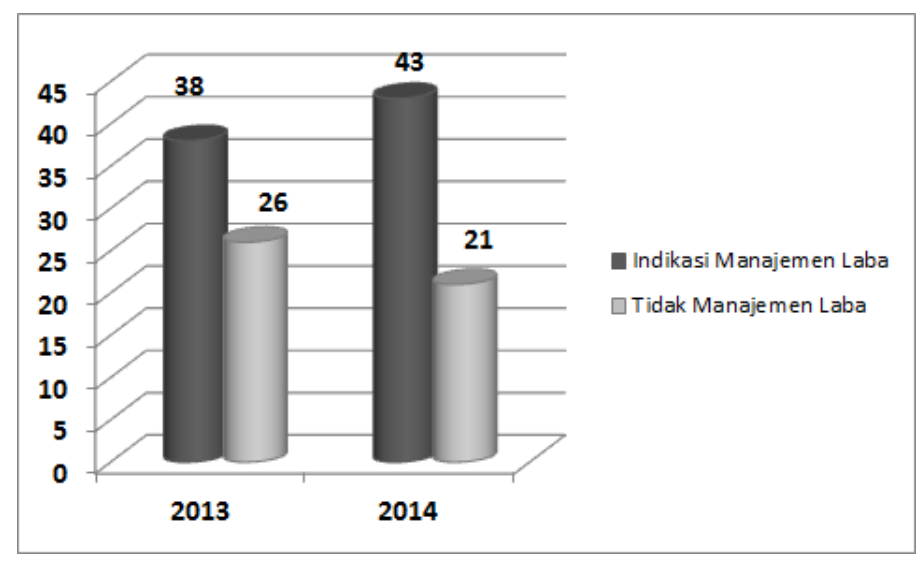


Berdasarkan Gambar1 terlihat bahwa indikasi perusahaan manufaktur di Indonesia melakukan manajemen laba riil masing-masing sebesar 38 dan 43 dari 64 perusahaan, atau sebesar 59\% dan 67\%, untuk tahun 2013 dan tahun 2014. Sedangkan yang tidak melakukan manajemen laba masing-masing sebanyak 26 dan 21 dari 64 perusahaan atau 41\% dan 33\% untuk tahun 2013 dan 2014.

Indikasi praktek manajemen laba riil tersebut ternyata berimbas pada penyajian laporan keuangan yang tidak berintegritas. Dengan menggunakan market to book value sebagai ukuran konservatisme (Beaver dan Ryan, 2000) sebagai proksi integritas laporan keuangan, ternyata dari 64 perusahaan tersebut hanya 34 perusahaan atau 53\% pada tahun 2013 dan 35 perusahaan atau 55\% pada tahun 2014 yang dinilai berintegritas menyajikan laporan keuangannya, yaitu memiliki market to book ratio lebih dari satu, yang dapat dilihat melalui gambar 2 berikut ini.

\section{Gambar 2. \\ Integritas Laporan Keuangan \\ Perusahaan Manufaktur di Indonesia 2013-2014}

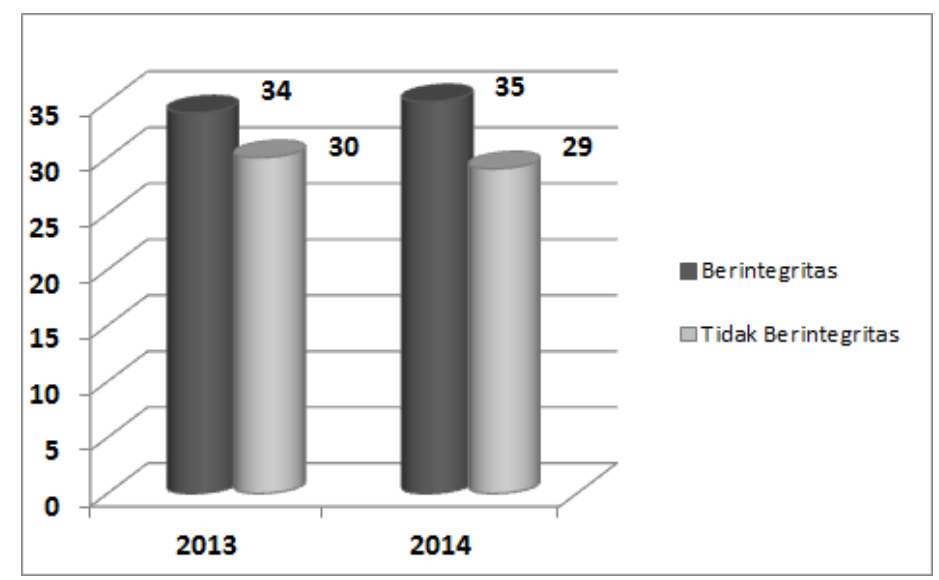

Grafik 2 menunjukkan bahwa hanya 34 perusahaan atau 53\% di tahun 2013 dan 35 atau 55\% di tahun 2014 perusahaan yang laporan keuangannya dinilai berintegritas. Dengan demikian patut dipertanyakan mengenai kemampuan perusahaan dalam menyajikan laporan keuangan yang berintegritas, mengingat masih ada sekitar $47 \%$ dan $45 \%$ perusahaan yang memiliki market to book value kurang dari satu.

Tidak berintegritasnya laporan keuangan yang disajikan tentu menjadi pertanyaan banyak pihak terkait implementasi tata kelola (corporate governance) perusahaan manufaktur di Indonesia. Menurut Endri (2012) konsep corporate governance pada intinya merupakan perluasan konsep yang mengatur hubungan antara pemilik dengan manajemen perusahaan atau permasalahan keagenan (agencyproblems) sehingga corporate governance diperlukan untuk mengurangi permasalahan tersebut. Dalam prakteknya, mekanisme corporate governance dilakukan dengan keberadaan kepemilikan institusional, komisaris independen dan audit yang berkualitas. 
Investor institusional merupakan investor yang berpengalaman sehingga dapat melakukan monitoring dengan lebih efektif. Terkait kepemilikan institusional dengan integritas laporan keuangan, beberapa penelitian memberikan hasil yang tidak konsisten. Penelitian Moghaddam, et al. (2013), Ramalingegowda dan Yu (2011), Wulandari dan Budiartha (2014), Aljufri (2014), serta Putra dan Muid (2012) menunjukkan bahwa kepemilikan institusional memiliki pengaruh positif terhadap integritas laporan keuangan. Namun hasil berbeda diperoleh dalam Penelitian Kootanaee, et al. (2013) serta Santoso dan Meiden (2013) yang menyimpulkan bahwa terdapat pengaruh negatif antara kepemilikan institusional dengan integritas laporan keuangan yang diproksikan dengan konservatisme.

Demikian pula ketika komposisi komisaris independen diteliti pengaruhnya terhadap integritas laporan keuangan, juga belum memberikan hasil yang konsisten. Penelitian Al-Sraheen, et al. (2014), Saksakotama dan Cahyonowati (2014), Jama'an (2008) menunjukkan bahwa proporsi komisaris independen berpengaruh positif terhadap integritas laporan keuangan. Sedangkan penelitian Santoso dan Meiden (2013) menyimpulkan bahwa komisaris independen memiliki pengaruh yang negatif terhadap integritas laporan keuangan.

Selanjutnya penelitian untuk mengetahui bagaimana pengaruh kualitas audit terhadap integritas laporan keuangan, diantaranya dilakukan oleh Paulo, et al. (2013), Reyad (2012), Saputra, dkk. (2014), Putra dan Muid (2012), serta Santoso dan Meiden (2013) telah menunjukkan hasil bahwa kualitas audit berpengaruh positif terhadap integritas laporan keuangan, sedangkan Aljufri (2014) hasil penelitiannya menunjukkan bahwa kualitas audit berpengaruh negatif terhadap integritas laporan keuangan.

Dengan hasil yang belum konsisten tersebut, penelitian ini berupaya untuk menguji kembali bagaimana pengaruh corporate governance dengan mekanismenya yang terdiri atas kepemilikan institusional, komisaris independen, dan kualitas audit terhadap integritas laporan keuangan untuk perusahaan manufaktur yang terdaftar di Bursa Efek Indonesia.

\section{B. KAJIAN PUSTAKA}

\section{Corporate Governance}

Corporate governance merupakan perluasan konsep yang mengatur hubungan antara manajemen dengan investor yang memungkinkan timbulnya agency problems. Jensen dan Meckling (1976) menjelaskan bahwa agency problem merupakan suatu kondisi ketika pengelola perusahaan (manajer) tidak bekerja secara optimal dalam rangka memaksimalkan kekayaan pemilik (investor) karena adanya conflict of interest yang berdampak pada munculnya agency cost. Hal ini dimungkinkan karena dengan kelebihan informasi yang dimilikinya (asymetric information) para manajer dapat bertindak atau mengambil keputusan yang hanya menguntungkan dirinya namun mengorbankan kepentingan pemilik.

Watts dan Zimmerman (1990) menyatakan bahwa laporan keuangan yang dibuat dengan angka-angka akuntansi diharapkan dapat meminimalkan konflik diantara para pihak yang berkepentingan. Laporan keuangan sebagai bentuk 
pertanggungjawaban kinerja manajemen disampaikan, dengan hal itu investor dan pihak lainnya dapat menilai, mengukur, dan mengawasi sampai sejauh mana manajemen bekerja untuk meningkatkan kesejahteraan para investor. Namun demikian, penyampaian laporan keuangan yang diharapkan dapat mengurangi konflik keagenan ternyata dapat dimanfaatkan oleh manajemen untuk mendapatkan keuntungan yang lebih besar. Akuntansi yang dicatat dengan basis akrual (accrual basis) merupakan subyek managerial discretion, karena fleksibilitas yang diberikan dapat memberikan dorongan kepada manajer untuk memodifikasi laporan keuangan agar dapat menghasilkan laporan laba seperti yang diinginkan, meskipun menciptakan distorsi dalam pelaporan laba (Watts dan Zimmerman, 1986). Salah satu cara yang diharapkan dapat digunakan untuk mengontrol biaya keagenan yaitu dengan menerapkan tata kelola perusahaan yang baik (good corporate governance).

Dengan demikian corporate governance merupakan konsep yang didasarkan pada teori keagenan dan diharapkan bisa berfungsi sebagai alat untuk memberikan keyakinan kepada para investor bahwa mereka akan menerima return atas dana yang telah mereka investasikan. Corporate governance berkaitan dengan bagaimana para investor yakin bahwa manajer akan memberikan keuntungan bagi mereka, yakin bahwa manajer tidak akan mencuri/menggelapkan atau menginvestasikan ke dalam proyek-proyek yang tidak menguntungkan berkaitan dengan dana yang telah ditanamkan oleh investor, dan berkaitan dengan bagaimana para investor mengontrol para manajer (Shleifer dan Vishny, 1997).

Babic (2005) menyatakan bahwa corporate governance dapat berbeda tergantung atas mekanisme pemilik perusahaan dalam mempengaruhi manajer. Secara umum terdapat dua jenis mekanisme corporate governance, yaitu (1) mekanisme internal corporate governance merupakan cara pengendalian perusahaan dengan menggunakan berbagai elemen yang ada di dalam organisasi, misalnya dengan kepemilikan saham oleh para manajer, dan (2) mekanisme eksternal corporate governance merupakan cara pengendalian perusahaan dengan menggunakan mekanisme eksternal perusahaan misalnya dengan menghadirkan reputational agent seperti profesi akuntan. Mekanisme eksternal bertujuan untuk mendisiplinkan perilaku pihak insider agar lebih transparan dan accountable dalam mengelola perusahaan. Mekanisme goood corporate governance ditandai dengan adanya beberapa proksi, yang diantaranya adalah kepemilikan institusional, komisaris independen, dan kualitas audit (Guna dan Herawaty, 2010; Jao dan Pagalung, 2011).

\section{Integritas Laporan Keuangan}

Laporan keuangan dikatakan berintegritas apabila laporan keuangan memenuhi kualitas reliability (Hardiningsih, 2010), sedangkan Martani, dkk (2012) menjelaskan bahwa informasi memiliki kualitas reliability jika bebas dari pengertian yang menyesatkan, kesalahan material, dan dapat diandalkan pemakainya sebagai penyajian yang tulus atau jujur (faithful representation) dari yang seharusnya disajikan atau yang secara wajar diharapkan dapat disajikan.

Terkait dengan reliability, Mayangsari (2003) menyatakan bahwa laporan keuangan yang reliable atau berintegritas dapat dinilai dengan penggunaan prinsip 
konservatisme. Konservatisme merupakan salah satu prinsip yang digunakan oleh akuntansi dalam menghadapi dua atau lebih alternatif dalam penyusunan laporan keuangan. Konsep konservatisme akuntansi dalam pelaporan keuangan bertujuan untuk mengakui, mengukur, dan melaporkan nilai aset dan pendapatan yang rendah, serta kewajiban dan beban yang tinggi (Jama'an, 2008). Hal ini berarti bahwa konsep konservatisme berimplikasi terhadap prinsip akuntansi yang akan mengakui beban atau kerugian yang mungkin akan terjadi, namun tidak dengan segera mengakui pendapatan atau laba yang akan terjadi walaupun kemungkinannya besar. Hal ini sejalan dengan apa yang dinyatakan oleh Baridwan (2002) bahwa apabila terdapat lebih dari satu alternatif tersedia maka sikap konservatif ini cenderung memilih alternatif yang tidak akan membuat aktiva dan pendapatan terlalu besar.

Wolk et al. (2000) serta Givoly dan Hayn (2002) berpendapat bahwa konservatisme merupakan masalah penting bagi investor dan terdapat indikasi kecenderungan peningkatan konservatisme secara global. Hal ini karena penerapan akuntansi konservatif dapat memberikan manfaat bagi perusahaan seperti dinyatakan oleh Watts (2003) bahwa konservatisme dapat membatasi perilaku oportunistik manajer, meningkatkan nilai perusahaan, mengurangi potensi tuntutan hukum, dan mendorong ditaatinya peraturan oleh manajer.

Meskipun prinsip konservatisme telah diakui dan banyak digunakan sebagai dasar penyusunan laporan keuangan namun beberapa pihak masih meragukan manfaat konservatisme. Konservatisme dianggap sebagai sistem akuntansi yang bias karena berangkat dari konsep yang mengakui biaya dan kerugian lebih cepat, mengakui pendapatan dan keuntungan lebih lambat, menilai aktiva dengan nilai yang terendah dan kewajiban dengan nilai yang tertinggi (Basu, 1997; Feltham dan Ohlson, 1995; Penman dan Zhang, 2002). Pandangan lain beranggapan bahwa metode akuntansi konservatif akan mencerminkan laba minimal yang dapat diperoleh perusahaan, dengan demikian angka laba yang disusun bukan merupakan laba yang dibesar-besarkan nilainya, sehingga dapat dinilai sebagai laba yang berkualitas. Bukti empiris menunjukkan bahwa penerapan International Financial Reporting Standard (IFRS) dengan fair valuenya ternyata tidak menghilangkan praktek konservatisme akuntansi. Menetapkan nilai wajar sewajar-wajarnya justru mendorong penyedia informasi akuntansi untuk lebih berhati-hati dalam mengungkapkan informasi (Handojo, 2012). Hal ini sejalan dengan hasil penelitian Bouwhuis (2008) yang menemukan bahwa tingkat konservatisme ternyata meningkat di Jerman dan Perancis setelah pengenalan IFRS, namun tingkat konservatisme di Inggris tidak berubah.

Alasan penggunaan konservatisme sebagai proksi integritas laporan keuangan adalah bahwa, konservatisme identik dengan laporan keuangan yang understate sehingga risikonya lebih kecil dibandingkan dengan laporan keuangan yang overstate. Laporan keuangan yang memenuhi karakteristik tersebut dinilai akan menjadi lebih reliable dan memenuhi syarat kualitas informasi, dan ini sejalan dengan apa yang dinyatakan oleh Mayangsari dan Wilopo (2002) bahwa prinsip konservatisme secara intuitif dapat bermanfaat karena digunakan untuk memprediksi kondisi di masa depan yang sesuai dengan tujuan laporan keuangan, 
dan karakteristik informasi dengan prinsip konservatisme ini dapat menjadi salah satu faktor untuk meningkatkan integritas dalam laporan keuangan.

\section{Pengaruh Kepemilikan Institusional terhadap Integritas Laporan Keuangan}

Pengawasan perlu dilakukan karena adanya pemisahan antara kepemilikan dan pengelolaan yang akan menimbulkan masalah keagenan (agency problem). Mekanisme pengawasan merupakan suatu hal yang penting dalam sebuah perusahaan. Salah satu pengawasan yang dapat dilakukan adalah melalui monitoring oleh investor institusional, yang dapat mendorong manajemen untuk lebih fokus pada pencapaian kinerjanya sehingga dapat mengurangi perilaku mementingkan diri sendiri para manajer (Jama'an, 2008).

Moghaddam, et al. (2013) dalam penelitiannya menyimpulkan bahwa kepemilikan institusional memiliki pengaruh positif terhadap laba konservatif, demikian pula Ramalingegowda dan Yu (2011) menjelaskan bahwa perusahaan dengan kepemilikan institusional yang tinggi ternyata lebih membutuhkan laporan keuangan yang konservatif. Selanjutnya Jama'an (2008) menyimpulkan bahwa corporate governance dengan proksi kepemilikan saham institusional berpengaruh positif signifikan terhadap integritas laporan keuangan. Demikian pula penelitian Wulandari dan Budiartha (2014), Aljufri (2014), serta Putra dan Muid (2012) menunjukkan bahwa kepemilikan institusional memiliki pengaruh positif signifikan terhadap integritas laporan keuangan. Hal ini mengindikasikan bahwa kepemilikan institusional cukup memiliki kemampuan untuk melakukan pengawasan yang intensif, sehingga hipotesis yang diajukan adalah sebagai berikut:

$\mathrm{H}_{1}$ : Kepemilikan institusional berpengaruh positif terhadap integritas laporan keuangan.

\section{Pengaruh Komisaris Independen terhadap Integritas Laporan Keuangan}

Fama dan Jensen (1983) menyatakan bahwa komisaris independen dapat berperan sebagai penengah dalam perselisihan yang terjadi diantara para manajer internal, melakukan pengawasan terhadap kebijakan manajemen dan memberikan masukan kepada manajemen. Menurut Wardhani (2008) komisaris independen adalah pihak yang tidak terafiliasi dengan pemegang saham pengendali, anggota direksi dan dewan komisaris lain, dan perusahaan itu sendiri baik dalam bentuk hubungan bisnis maupun kekeluargaan. Dengan adanya proporsi komisaris independen yang lebih tinggi, maka diharapkan dapat mendorong pengungkapan informasi yang lebih andal dan netral (Oliviera et al., 2011).

Penelitian Al-Sraheen, et al. (2014), menyimpulkan bahwa komisaris independen memiliki pengaruh yang positif terhadap konservatisme, selanjutnya penelitian Saksakotama dan Cahyonowati (2014), Jama'an (2008) juga menunjukkan bahwa proporsi komisaris independen berpengaruh positif signifikan terhadap integritas laporan keuangan. Pengaruh yang positif menunjukkan bahwa dengan adanya pengawasan komisaris independen maka pihak manajemen tidak memiliki kebebasan dalam menentukan prinsip akuntansi yang digunakan, sehingga manajemen dapat dipaksa untuk menerapkan prinsip 
akuntansi yang konservatif dalam penyusunan laporan keuangan (Santoso dan Meiden, 2013). Dengan demikian, hipotesis yang diajukan adalah sebagai berikut:

$\mathrm{H}_{2}$ : Komisaris independen berpengaruh positif terhadap integritas laporan keuangan.

\section{Pengaruh Kualitas Audit terhadap Integritas Laporan Keuangan}

Kualitas audit didefinisikan sebagai kemampuan kantor akuntan dalam memahami bisnis klien (Bodie, et al. 2008). Sedangkan Aljufri (2014) berpendapat bahwa kualitas audit merupakan segala kemungkinan auditor dalam melaksanakan penugasannya mampu menemukan pelanggaran dalam sistem akuntansi klien dan melaporkannya dalam laporan keuangan auditan. Sjarifuddin dan Widyastuti (2014) menyatakan bahwa kualitas audit sangat berpengaruh dalam pelaporan keuangan, karena audit atas laporan keuangan bertujuan untuk menilai kewajaran laporan keuangan dimana dalam melaksanakan tugasnya auditor berpedoman pada standar auditing dan kode etik akuntan publik.

Penelitian Paulo, et al. (2013) menyimpulkan bahwa ukuran kantor akuntan sebagai proksi kualitas audit memiliki pengaruh yang positif dan signifikan terhadap informasi akuntansi yang konservatif, demikian pula Reyad (2012) menyimpulkan bahwa kualitas audit memiliki hubungan yang positif dan signifikan terhadap konservatisme akuntansi. Lebih lanjut, Saputra, dkk. (2014), Putra dan Muid (2012), serta Santoso dan Meiden (2013) telah menunjukkan hasil bahwa kualitas audit berpengaruh positif signifikan terhadap integritas laporan keuangan. Berdasarkan alasan tersebut maka hipotesis yang diajukan adalah sebagai berikut:

$\mathrm{H}_{3}$ : Kualitas audit berpengaruh positif terhadap integritas laporan keuangan.

\section{Pengaruh Kepemilikan Institusional, Komisaris Independen, dan Kualitas Audit Secara Bersama-sama terhadap Integritas Laporan Keuangan}

Kehadiran kepemilikan institusional, komisaris independen, dan kualitas audit yang baik, tentu akan meningkatkan kontrol atas penyelenggaraan perusahaan termasuk pelaporan keuangan, sehingga mendorong tersusunnya laporan keuangan yang berintegritas. Berdasarkan uraian di atas, maka hipotesis yang diajukan adalah sebagai berikut :

$\mathrm{H}_{4}$ : Kepemilikan institusional, komisaris independen, dan kualitas audit secara bersama-sama berpengaruh terhadap integritas laporan keuangan.

\section{METODE PENELITIAN}

\section{Data Penelitian}

Data sekunder digunakan dalam penelitian ini, yaitu berupa laporan keuangan perusahaan manufaktur yang terdaftar di Bursa Efek Indonesia untuk periode 2011-2014 yang diperoleh melalui website www.idx.co.id dan Indonesian Capital Market Directory (ICMD). Data dianalisis dengan regresi linier berganda untuk selanjutnya diolah dengan menggunakan program Statistical Package for the Social Sciences (SPSS) versi 21. 
Berdasarkan purposive sampling maka banyaknya perusahaan yang diteliti adalah sebagai berikut :

Tabel 1.

\section{Sampel Penelitian}

\begin{tabular}{clc}
\hline NO. & \multicolumn{1}{c}{ KRITERIA SAMPEL } & JUMLAH \\
\hline 1. & Perusahaan yang termasuk dalam industri manufaktur & 93 \\
2. & Laporan keuangan tahun 2011-2014 tidak lengkap & $(11)$ \\
3. & Perusahaan mengalami delisting selama periode pengamatan & - \\
4. & $\begin{array}{l}\text { Data keuangan yang berkaitan dengan variabel penelitian tidak } \\
\text { lengkap }\end{array}$ & $(20)$ \\
& \multicolumn{2}{c}{ Jumlah } \\
\hline
\end{tabular}

Sumber : Data diolah

\section{Operasionalisasi Variabel}

Pada model yang menjadi variabel terikat adalah integritas laporan keuangan, dengan variabel bebas terdiri atas kepemilikan institusional, komisaris independen, dan kualitas audit, dengan operasionalisasi variabel seperti disajikan pada tabel 2 berikut ini.

Tabel 2.

\section{Operasionalisasi Variabel}

\begin{tabular}{|c|c|c|c|}
\hline VARIABEL & KONSEP & DIMENSI & INDIKATOR \\
\hline Kepemilikan & Pengawasan dengan & Pemilik & (Jumlah saham \\
\hline Institusional & $\begin{array}{l}\text { kehadiran pemilik } \\
\text { institusi }\end{array}$ & $\begin{array}{l}\text { berbentuk } \\
\text { institusi }\end{array}$ & $\begin{array}{l}\text { institusi/total saham) } \\
\text { x } 100 \%\end{array}$ \\
\hline Komisaris & Pengawasan dengan & Dewan & (Komisaris dari luar / \\
\hline Independen & $\begin{array}{l}\text { kehadiran dewan } \\
\text { komisaris } \\
\text { independen }\end{array}$ & $\begin{array}{l}\text { komisaris yang } \\
\text { tidak terafiliasi }\end{array}$ & $\begin{array}{l}\text { seluruh dewan } \\
\text { komisaris)x } 100 \%\end{array}$ \\
\hline Kualitas Audit & $\begin{array}{l}\text { Menjamin } \\
\text { kewajaran laporan } \\
\text { keuangan }\end{array}$ & KAP bereputasi & $\begin{array}{l}\text { Dummy data. The big } \\
\text { four nilai } 1 \text {, lainnya } \\
\text { nilai } 0\end{array}$ \\
\hline $\begin{array}{l}\text { Integritas } \\
\text { Laporan } \\
\text { Keuangan }\end{array}$ & $\begin{array}{l}\text { Laporan keuangan } \\
\text { yang reliable }\end{array}$ & Konservatisme & Market to book ratio \\
\hline
\end{tabular}

\section{HASIL DAN PEMBAHASAN}

\section{Uji Asumsi Klasik}

Berdasarkan uji asumsi klasik diketahui bahwa nilai VIF kurang dari 10 maka dapat disimpulkan tidak terdapat gejala multikolonieritas antar variabel independen. Kemudian nilai DW diketahui sebesar 0,838 berada diantara -2 dan +2 , yang artinya tidak terdapat gejala autokorelasi. Dalam scatterplot juga tidak ada pola yang jelas, serta titik-titik menyebar di atas dan di bawah angka 0 pada sumbu Y, dengan demikian maka dapat disimpulkan tidak terjadi 
heteroskedastisitas dalam model. Selanjutnya untuk normalitas, diketahui bahwa data menyebar disekitar garis diagonal dan mengikuti arah garis diagonal, hal ini menunjukkan bahwa data berdistribusi normal. Dengan demikian uji asumsi klasik telah memenuhi untuk data penelitian.

\section{Uji Signifikan Parameter Individual (Uji t)}

Untuk mengetahui apakah variabel independen secara parsial berpengaruh signifikan terhadap variabel dependen maka dilakukan uji t.

Tabel 3.

Uji t

Coefficients $^{\mathrm{a}}$

\begin{tabular}{|c|c|c|c|c|c|c|}
\hline \multirow[b]{2}{*}{ Mode } & & \multicolumn{2}{|c|}{$\begin{array}{l}\text { Unstandardized } \\
\text { Coefficients }\end{array}$} & \multirow{2}{*}{$\begin{array}{c}\begin{array}{c}\text { Standardized } \\
\text { Coefficients }\end{array} \\
\text { Beta }\end{array}$} & \multirow[b]{2}{*}{$\mathrm{t}$} & \multirow[b]{2}{*}{ Sig. } \\
\hline & & B & Std. Error & & & \\
\hline \multirow[t]{4}{*}{1} & (Constant) &,- 478 & ,229 & & $-2,085$ & ,038 \\
\hline & Kepins & $-1,160$ & ,329 &,- 184 & $-3,523$ &, 001 \\
\hline & Komind & 1,132 &, 534 & ,109 & 2,119 & ,035 \\
\hline & Klaud & 1,287 & , 128 & ,525 & 10,056 & ,000 \\
\hline
\end{tabular}

Uji Hipotesis 1 : Kepemilikan institusional berpengaruh positif terhadap integritas laporan keuangan.

Berdasarkan tabel 3 terlihat bahwa kepemilikan institusional memiliki nilai koefisien -1,160 dan nilai Sig. 0,001 sehingga hasil penelitian menunjukkan bahwa kepemilikan institusional berpengaruh negatif signifikan terhadap integritas laporan keuangan. Dengan demikian $\mathrm{H}_{1}$ tidak terbukti dalam penelitian ini.

Penelitian ini tidak mendukung hasil yang disimpulkan oleh Wulandari dan Budiartha (2014), Aljufri (2014), serta Putra dan Muid (2012) yang menunjukkan bahwa kepemilikan institusional memiliki pengaruh positif signifikan terhadap integritas laporan keuangan. Penelitian ini mendukung hasil yang diperoleh peneliti Kootanaee, et al. (2013) dan Santoso dan Meiden (2013) yang menyimpulkan terdapat pengaruh negatif, namun dalam penelitian keduanya menunjukkan hasil yang tidak signifikan.

Hasil penelitian ini mengindikasikan bahwa kepemilikan institusional tidak cukup memiliki kemampuan untuk melakukan pengawasan yang intensif untuk mewujudkan pelaporan keuangan yang berintegritas.

Uji Hipotesis 2 : Komisaris independen berpengaruh positif terhadap integritas laporan keuangan.

Berdasarkan tabel 3 terlihat bahwa komisaris independen memiliki nilai koefisien 1,132 dan nilai Sig. 0,035 sehingga hasil penelitian menunjukkan bahwa 
komisaris independen berpengaruh positif signifikan terhadap integritas laporan keuangan, dengan demikian $\mathrm{H}_{2}$ terbukti dalam penelitian ini.

Penelitian ini mendukung hasil yang disimpulkan oleh Al-Sraheen, et al. (2014), Saksakotama dan Cahyonowati (2014), serta Jama'an (2008) yang juga menyatakan bahwa proporsi komisaris independen berpengaruh positif signifikan terhadap integritas laporan keuangan.

Dengan demikian hasil penelitian ini menunjukkan bahwa keberadaan komisaris independen ternyata mampu melakukan pengawasan terhadap perusahaan dengan baik sehingga mendorong tersusunnya laporan keuangan yang berintegritas.

Uji Hipotesis 3 : Kualitas audit berpengaruh positif terhadap integritas laporan keuangan.

Berdasarkan tabel 3 terlihat bahwa kualitas audit memiliki nilai koefisien 1,287 dan nilai Sig. 0,000 sehingga hasil penelitian menunjukkan bahwa kualitas audit berpengaruh positif signifikan terhadap integritas laporan keuangan, dengan demikian $\mathrm{H}_{3}$ terbukti dalam penelitian ini.

Penelitian ini mendukung hasil yang disimpulkan oleh Saputra, dkk. (2014), Paulo, et al. (2013), Santoso dan Meiden (2013), Reyad (2012), serta Putra dan Muid (2012), yang menyimpulkan bahwa kualitas audit berpengaruh positif signifikan terhadap integritas laporan keuangan.

Berdasarkan hasil penelitian ini ternyata terbukti bahwa kualitas audit mampu memberikan dampak pada meningkatnya kepatuhan terhadap standar akuntansi keuangan serta transparannya laporan keuangan yang disajikan sehingga dapat meningkatkan integritas laporan keuangan.

\section{Koefisien Determinasi (Adjusted $\boldsymbol{R}^{2}$ )}

Berdasarkan tabel 4 terlihat bahwa nilai Adjusted $R$ Square sebesar 0,343 yang menunjukkan bahwa keseluruhan proksi corporate governance mampu menjelaskan variasi nilai variabel integritas laporan keuangan sebesar 34,3\%, sedangkan sisanya sebesar $65,7 \%$ dipengaruhi oleh faktor lain yang tidak diteliti dalam penelitian ini.

Tabel 4.

Koefisien Determinasi

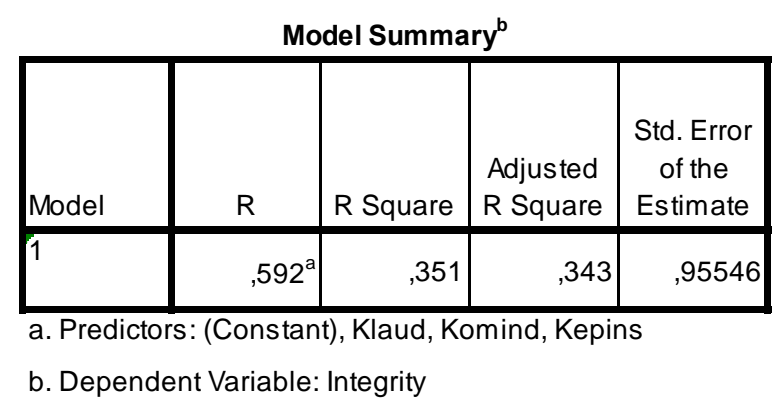




\section{E. SIMPULAN}

Berdasarkan uraian dan pembahasan pada bagian terdahulu, maka kesimpulannya adalah sebagai berikut :

1. Kepemilikan institusional berpengaruh negatif signifikan terhadap integritas laporan keuangan.

2. Komisaris independen berpengaruh positif signifikan terhadap integritas laporan keuangan.

3. Kualitas audit berpengaruh positif signifikan terhadap integritas laporan keuangan.

4. Kepemilikan institusional, komisaris independen dan kualitas audit secara bersama-sama berpengaruh signifikan terhadap integritas laporan keuangan.

\section{DAFTAR PUSTAKA}

Al-Sraheen, Dea'a Al-Deen Omar., Faudziah Hanim Fadzil, Syed Soffian Bin Syed Ismail, Othman Yeop Abdullah. (2014). "Does Corporate Governance Matter? Evidence from Accounting Conservatism Practices among Jordanian Listed Companies", International Journal of Learning and Development, Vol. 4, No. 4, 64-80.

Aljufri. (2014). "Dampak Audit Quality dan Corporate Governance Terhadap Integritas Laporan Keuangan". Jurnal Ilmiah Ekonomi dan Bisnis, Vol.11 No.2, 267-280.

Babic, Verica. (2005). "Corporate Governance Problem in Trasition Economies", Ekonomist 33 No.2, 133-143.

Beaver, W.H., R. Ryan. (2000). "Biases and Lags in Book Value and Their Effect on The Ability of The Book to Market Ratio to Predict Book Return on Equity." Journal Accounting Research, Vol.8, No.1, 127-148.

Baridwan, Zaki. (2002). Sistem Akuntansi : Penyusunan Prosedur dan Metode. Edisi Kelima. Yogyakarta: Penerbit BPFE Yogyakarta.

Basu, Sudipta. (1997). "The Conservatism Principle and The Asymmetric Timeliness of Earnings." Journal of Accounting and Ecocomics 24, 3-37. 
Bodie, Z., Kane, A., \& Marcus, A. J. (2008). Investments. Seventh Edition. New York: McGraw-Hill

Bouwhuis, Wouter. (2008). "The effect of earnings management on earnings conservatism after the introduction of IFRS", Working Paper, Universiteit van Amsterdam.

Damayanti, Fitri., Rochmi. (2014). "Pengaruh Reputasi Auditor dan Mekanisme Corporate Governance Terhadap Integritas Laporan (Studi Empiris Pada Perusahaan Manufaktur yang Terdaftar di Bursa Efek Indonesia Periode 2008-2010)." Jurnal Bisnis dan Manajemen ESENSI. Vol.4 No.3, 1-15.

Endri (2012). "Pengaruh Mekanisme Corporate Governance Terhadap Kinerja Profitabilitas Perbankan Syariah di Indonesia."Jurnal Keuangan dan Perbankan, Vol.16, No.2, 164-274.

Fama, E., Jensen, M. (1983). "Separation of Ownership and Control", Journal of Law and Economics 26 (June), 301-325.

Feltham, J. And Ohlson. (1995). "Valuation and Clean Surplus Accounting for Operating and Financial Activities." Contemporary Accounting Reserach 11, 689-731.

Gayatri, Ida Ayu Sri., I Dewa Gede Dharma Suputra. (2013). "Pengaruh Corporate Governance, Ukuran Perusahaan, dan Leverage Terhadap Integritas Laporan Keuangan." E-Jurnal Akuntansi Universitas Udayana, 345-360.

Givoly, Dan., Carla Hayn. (2002). "Rising Conservatism: Implications for Financial Analysis." Financial Analysis Journal, SRRN Working Paper, March.

Ghozali, Imam. (2013). Aplikasi Analisis Multivariate Dengan Program IBM SPSS 21 Update PLS Regresi. Semarang: Badan Penerbit Universitas Diponegoro.

Guna, Welvin I.., Arleen Herawaty. (2010). "Pengaruh Mekanisme Good Corporate Governance, Independensi Auditor, Kualitas Audit dan Faktor Lainnya Terhadap Manajemen Laba." Jurnal Bisnis dan Akuntansi, Vol.12 No.1, 53-68.

Hardiningsih, Pancawati. (2010). "Pengaruh Independensi, Corporate Governance, dan Kualitas Audit Terhadap Integritas Laporan Keuangan.” Kajian Akuntansi. Vol.2 No.1, 61-76. 
Hasan, Sjarifuddin., Tri Widyastuti. (2014). Auditing. Jakarta: Penerbit Global Future Institute.

Handojo, Irwanto. (2012). "Sekelumit Konservatisme Akuntansi", Media Bisnis, $1-16$.

Jao, Robert., Gagaring Pagalung. (2011). "Corporate Governance, Ukuran Perusahaan, dan Leverage Terhadap Manajemen Laba Perusahaan Manufaktur Indonesia." Jurnal Akuntansi dan Auditing, Vol.8 No.1, 43-54.

Jama'an. (2008). "Pengaruh Mekanisme Corporate Governance, dan Kualitas Kantor Akuntan Publik Terhadap Integritas Laporan Keuangan". Prosiding, Simposium Nasional Akuntansi XI, Pontianak.

Jensen, Michael C., William H. Meckling. (1976). "Theory of the Firm: Managerial Behaviour, Agency Cost, and Ownership Structure."Journal of Financial Economics, Vol.3 No. 4, 305-360.

Kootanaee, Akbar Javadian., Jalal Seyyedi, Morteza Nedaei, Milad Javadian Kootanaee, (2013), "Accounting Conservatism and Corporate Governance's Mechanisms: Evidence from Tehran Stock Exchange", International Journal of Economics, Business and Finance, Vol. 1, No. 10, 301-319.

Leuz, Christian., Dhananjay Nanda, Peter D. Wysocki. (2002). "Earnings management and investor protection: an international comparison", http://papers.ssrn.com, diakses 10 Agustus 2016.

Martani, Dwi., Sylvia Veronica NPS, Ratna Wardhani, Aria Farahmita, Edward Tanujaya. (2012). Akuntansi Keuangan Menengah Berbasis PSAK. Buku 1. Jakarta: Penerbit Salemba Empat.

Mayangsari. (2003). “Analisis Pengaruh Independensi, Kualitas Audit, serta Mekanisme Corporate Governance terhadap Integritas Laporan Keuangan". Prosiding, Simposium Nasional Akuntansi VI, Surabaya.

Mayangsari, Sekar., Wilopo. (2002). 'Konservatisme Akuntansi, Value Relevance dan Discretionary Accrual: Implikasi Empiris Model FelthamOhlson.”, Jurnal Riset Akuntansi Indonesia, Vol.7, No.2, 154-178.

Moghaddam, Abdolkarim., Vahid Amirzadeh, Ali Ali Heidari. (2013). "Studying the Relationship between Institutional Ownership and Conservatism in Companies Accepted in Tehran Stock Exchange", International 
Journal of Academic Research in Accounting, Finance and Management Sciences, Vol. 3, No.1, 400-408.

Oliviera, Jonas., Lucia Lima Rodrigues, Russel Craig. (2011). "Risk-related disclosures by non-finance companies". Managerial Auditing Journal, Vol. 26, No. 9, 817-839.

Paulo, Lana Izadora Souza Lapa de Melo., Paulo Roberto Nóbrega Cavalcante, Edilson Paulo. (2013), "The Relationship Between Auditing Quality and Accounting Conservatism in Brazilian Companies", Journal of Education and Research in Accounting, Vol.7 No. 3, 293-314.

Penman, S., X. Zhang. (2002). "Accounting Conservatism, the Quality of Earnings, and Stock Returns." The Accounting Review 77 No.2, 237264.

Putra, Daniel Salfauz Tawakal., Dul Muid. (2012). "Pengaruh Independensi, Mekanisme Corporate Governance, Kualitas Audit, dan Manajemen Laba Terhadap Integritas Laporan Keuangan." Diponegoro Journal of Accounting, Vol.1, No.2, 1-9.

Rahiim, Defriando., Soliyah Wulandari. (2014). "Pengaruh Mekanisme Corporate Governance dan Kualitas Kantor Akuntan Publik Terhadap Integritas Laporan Keuangan." Jurnal Bisnis dan Manajemen ESENSI. Vol.4 No.3, 87-102.

Ramalingegowda, Santhosh., Yong Yu. (2011). "Institutional ownership and conservatism”, http://papers.ssrn.com, diakses 19 Juli 2016.

Ratmono, Dwi. (2010). "Manajemen Laba Riil dan Berbasis Akrual: Dapatkah Auditor yang Berkualitas Mendeteksinya?", Prosiding, Simposium Nasional AkuntansiXIII, Purwokerto.

Reyad, Sameh M. Reda. (2012). “Accounting Conservatism and Auditing Quality: an Applied Study On Egyptian Corporations", European Journal of Business and Management, Vol 4, No.21, 2012, 108-116.

Santoso, Widodo Budi,. Carmel Meiden. (2013). “Analisis Pengaruh Mekanisme Good Corporate Governance, Ketepatan Waktu Pelaporan, Kualitas Audit, dan Kepemilikan Saham Oleh Keluarga Terhadap Integritas Laporan Keuangan Perusahaan Manufaktur Yang Terdaftar Di BEI 2009-2011". Akuntansi Manajemen, Vol.2 No.2, 118-132.

Saksakotama, Paramita Hana., dan Nur Cahyonowati. (2014). "Determinan Integritas Laporan Keuangan Perusahaan Manufaktur di Indonesia", Diponegoro Journal of Accounting, Vol.3, No.2, 1-13. 
Saputra, Wahyudi., Desmiawati, Yuneita Anisma. (2014). "Pengaruh Mekanisme Good Corporate Governance, dan Ukuran Perusahaan Terhadap Integritas Laporan Keuangan (Studi Kasus pada Perusahaan Manufaktur Yang Terdaftar Di Bursa Efek Indonesia Periode 2012).” Jurnal JOM FEKON, Vol. 1 No. 2, 1-15.

Shleifer, A., Vishny, R.W. (1997). “A Survey of Corporate Governance”, Journal of Finance, Vol.2, No.2, 350-363.

Sjahrial, Dermawan., Djahotman Purba. (2013). Analisis Laporan Keuangan. Jakarta: Penerbit Mitra Wacana Media.

Wardhani, Ratna. (2008). "Tingkat Konservatisme Akuntansi di Indonesia dan Hubungannya dengan Karakteristik Dewan Sebagai Salah Satu Mekanisme Corporate Governance”. Prosiding, Simposium Nasional Akuntansi XI, Pontianak.

Watts, Ross L., Zimmerman, J.L. (1986). Positive Accounting Theory, New Jersey: Prentice Hall International, Inc.

(1990). "Positive Accounting Theory: A Ten Year Perspective." University Of Rochester. The Accounting Review. Vol. 65 No. 1, 131-156.

Watts, Ross L. (2003). "Conservatism in Accounting part I: explanations and implications". Accounting Horizons, Vol.17, No.3, 207-221.

Weygandt, Jerry J., Paul D. Kimmel, Donald E. Kieso. (2011). Financial Accounting IFRS Edition. New Jersey: John Wiley \& Sons.

Wulandari, N.P. Yani., I Ketut Budiartha. (2014). "Pengaruh Struktur Kepemilikan, Komite Audit, Komisaris Independen Dan Dewan Direksi Terhadap Integritas Laporan Keuangan”, e-Jurnal Akuntansi Universitas Udayana 7.3, 574-586

Wolk, H.L., M.G., Tearney, J.L. Dodd. (2000). Accounting Theory : $a$ Conceptual and Institutional Approach. Fifth Edition, Ohio: South Western College Publishing. 
